\title{
光ファイババンドルを利用するシンチレーション 測定系の $\Upsilon$ 線検出特性
}

$\begin{array}{llllll}\text { 正 員 } & \text { 新 } & \text { 田 } & \text { 陽 } & \text { (豐橋技科大) } \\ \text { 正 員 } & \text { 東 } & \text { 山 } & \text { 禎 } & \text { 夫 } & \text { (豊橋技科大) } \\ \text { 正 員 } & \text { 榎 } & \text { 本 } & \text { 茂 } & \text { 正 } & \text { (豊橋技科大) }\end{array}$

\section{1. まえがき}

代表的な放射線検出器の一つであるシンチレーショ ン検出器は, 通常シンチレータと光電子增倍管を一体 化してプローブを形成している。てのため高温, 強磁 界なざ条件の德い環境においては光電子增倍管が正常 亿動作せず，測定に支障を生ずることも多い。また， プローブと計数部との距離を十分とって測定を行う場 合, 光電子增倍管への高王電源線衫よびそれからの信 号線が長くなるため，周囲の電磁場による誘導雑音に 対する処置が必要亡なる。

これらの問題は, シンチレーションを光電子增倍管 まで伝送する何らかの媒体を設けてシンチレータと光 電子增倍管を分離し，後者を計数部近接，加つ安定 動作が可能な場所化設置することで解決できる。シン チレーションの伝送媒体として入手が容易な光ファイ バが誉げら机(1)，核融合炋環境における $\alpha$ 線，中性子 計測の試み(2)や，速絸鋳造用の電磁かくはん炣におけ るて線レベル計での実用例(3)が報告さ机ている。との 際,プローブを小非，整量化することによりパイプ 中，古るいは液中への捰入，遠隔測定など特殊な忘用 屯期待される。

本論文では，各種のシンチレータと光ファイババン ドルを組合せた検出部の $\gamma$ 線シンチレーション集光率 をモンテカルロ法によって計算すると其に，こ机に光 電子增倍管を加えた幾つかの测定系で $\gamma$ 線スペクトル

The Gamma*Ray Detection Characteristics of a Scintillation Counting System Using Optical Fiber Bundle. By Youichi Nitta, Member, Yoshio Higashiyama, Member \& Shigemasa Enomoto, Member (Department of Electrical and Electronic Engineering, Toyohashi University of Technology).

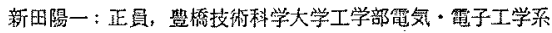

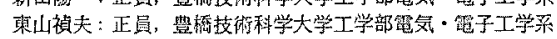
[现在, 近理大学工学部型気工学科]

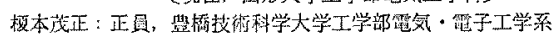

を観測し，上述の応用の基碟となる $\gamma$ 線検出特性につ いて検討した。

\section{2. モンテカルロシミュレーション}

〈2.1〉計算方法 シンチレータ内で発生したシ ンチレーションが光ファイババンドルに集められる割 合は、シンチレータの形状，材質などによって変化す る。てれを検討するため, シンチレータ内で発生した シンチレーションがその出射面から出射する割合（出 射率) と, シンチレータ・光フォイバ測定系において シンチレーションが光ファイババンドルに入射, 伝送 される割合 (集光率)をモンテカルロ法で計算した。

シンチレータは円柱状で光の出射面を除いて $\mathrm{MgO}$ 反射材で覆われており，出射面には光電子增倍管，あ るいは光ファイババンドルが密着されるものとして, 以下の過程沙従って計算を行った。計算に使用した物 理定数の值を表 1 に示した。

（1）シンチレータを図 1 亿示すように 64 個の同 体積のブロックに分割し，そこで発生したシンチレー ションの発光点は各ブロックの重心とする。

（2）各発光点们打汀る発生光子数は等しく 100 個 とし, 総数 6,400 個の光子について計算を行う。光子

表 1 シシュレーションに用いた物理定数

Table 1. The physical parameters used in the simulation.

\begin{tabular}{|c|c|c|}
\hline \multirow[t]{6}{*}{ 届折察 } & $\operatorname{Nal}(T 1)$ シンチレータ & 1.850 \\
\hline & $\mathrm{Bi}_{4} \mathrm{Ge}_{3} \mathrm{O}_{12}(\mathrm{BGO})$ シンチレータ & 2.150 \\
\hline & $\mathrm{MgO}$ 反射材 & 1.736 \\
\hline & PMT 入射悹 & 1.500 \\
\hline & 光ファイパ: $=ア$ & 1. 495 \\
\hline & 光フェイバ: クラッド & 1.402 \\
\hline \multicolumn{2}{|c|}{ シンチレータの地減衰長 ${ }^{(4)}$} & $2,000 \mathrm{~mm}$ \\
\hline \multirow[t]{2}{*}{ 反射率(5) } & $\mathrm{NaI}(\mathrm{Tl})-\mathrm{MgO}$ & 0.97 \\
\hline & $\mathrm{BGO}-\mathrm{MgO}$ & 0.98 \\
\hline
\end{tabular}




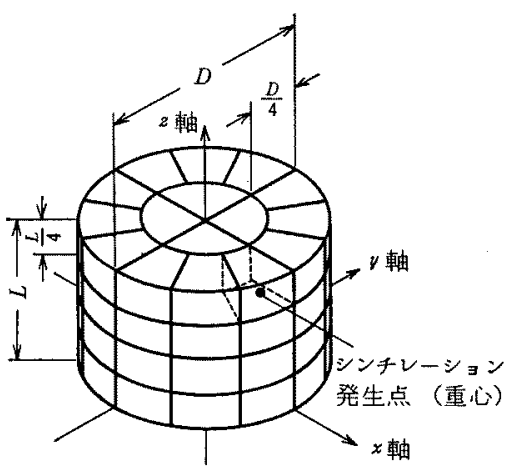

図 1 シンチレータの分割とシンチレーション 発生点

Fig. 1. Schematization of division of scintillator and scintillation point.

は $4 \pi$ 方向へランダムに放出される。

（3）光子数の咸衰は反射損失および吸収損失によ り生じる。

（4）シンチレータ境界面における光子の挙動は Lambert の法則(6)および Fresnel の法則(7)に従う。

（5）1個の光子に対する計算は，シンチレータよ り出射した場合，あるいは反射回数が 100 回を超えた とき打切る。

$\langle 2 \cdot 2\rangle$ 光子の出射率と出射面位置 - 角度分布

最初にシンチレータの形状，材質による光子の出射 率の変化ならでに出射面に㧍ける光子の位置・角度分
布を求めた。出射面に対向，密着する媒澌には光電子 增倍管入射空を考元，その属折率を 1.50 とした。

図 2(a)〜 (d) に，各種のシンチレータの出射面に おりる光子の位置・角度分有および光子の出射率の計 算結果を示す。位置分布は出射面を約 320 の同一面箖 に区切り，各要素に招ける出射率を求めたものであ る。角度分有は光子の出射角を調べて統計をとり，各 階級值の単位立体角で規格化した。階級の幅は $1^{\circ}$, 範 囲は 0 $90^{\circ}$ とし, $90 \sim 180^{\circ}$ の分布は $0 \sim 90^{\circ}$ の分布 を複写した。

図2の光子の総出射率を比較すると、シンチレータ の直径と長さの比が大いものほよ゙高い。乙れは各発 光点から出射面を見た立体角が大きく，少ない反射回 数で出射すると共に，出射するまでの通過距離加短く なるととによる。また同じ形状，大きさの場合， (a) $\mathrm{NaI}(\mathrm{Tl})$ と (d) $\mathrm{BGO}\left(\mathrm{Bi}_{3} \mathrm{Ge}_{4} \mathrm{O}_{12}\right)$ の雨シンチ レータを比較すると，後者の弫うが屈折率が大きいた め出射面で全反射される割合が高く；出射率は低い。

因 2 の光子の分布は，位圆的には各発光点加らの奇 与が平均している中心部が高く, 角度的に怔直方向 の出射率が高い。垂直方向への分布はシンチレータの 直径と長さの比が小くなるほど影著である。このよ うな形状では，低角度で出射する光子は侧面で反射を 繰返している場合が多く，減衰汃激しいためと考えら れる。

〈2.3〉光ファイババンドルへの集光率光ファ イババンドルを用いる場合, 直径の小さいバンドルが

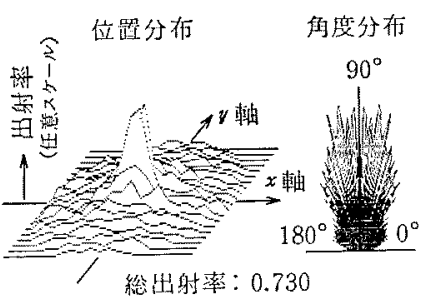

(a) $25.4 \mathrm{~mm}^{4} \times 25.4 \mathrm{~mm} \mathrm{NaI}(\mathrm{Tl})$

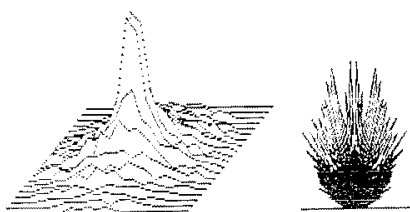

総出射率：0.858

(b) $25.4 \mathrm{~mm}^{\phi} \times 12.7 \mathrm{~mm} \mathrm{NaT}(\mathrm{T} 1)$

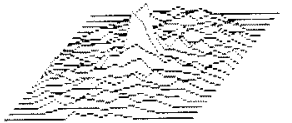

総出射率：0.531

(c) $12.7 \mathrm{~mm}^{\phi} \times 25.4 \mathrm{~mm} \mathrm{NaI}(\mathrm{Tl})$
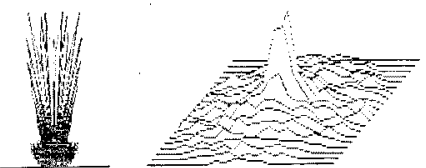

総出射率: 0.658

(d) $25.4 \mathrm{~mm} \phi 25.4 \mathrm{~mm} B \mathrm{BGO}$

图 2 シンチレータ出射面に叔ける出射光子の位置・角度分布

Fig. 2. Local distribution and angular distribution of output photons at the scintillator output plane coupled with PMT window. 
入手汃容易で，一般にはシンチレ一タ出射面と大きさ が一致しない。一方，シンチレーション集光率はバン ドル直倩やコア面積で決まるバンドルの有效受光面 積，ならびに光ファイバの開口数で決まる受光角なさ

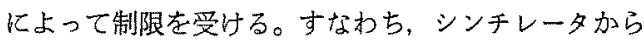
出射したものの光ファイバのコアに入射しない光子, ならびにフォイバの受光角內内で入射しない光子は集 光率に堵与しない。

計算ではアクリル系ファイバを想定し，開口数 0.5 で受光角 $60^{\circ}$ としたが，空気より届折率の高いシンチ レータと組合せる場合にはこれより小さくなり， $\mathrm{NaI}(\mathrm{T} 1)$ では $32.6^{\circ}, \mathrm{BGO}$ で $27.9^{\circ}$ となる。较っ $\tau$, 幾何学的条件が同じ場合, $\mathrm{NaI}(T 1)$ シンチレータ を用いるほうが策光率が良い。

25.4 吅めシンチレータとパンドルの断面積比

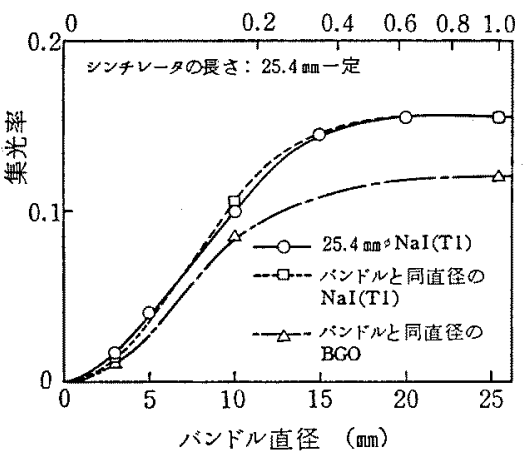

図 3 シンチレータ・光ファイババンドル 测定称における光子の集光率

Fig. 3. Scintillation collection efficiency calculated for the coupling of various scintillators and optical fiber bundles.
簡単化のため光ファイバのコア，クラッドおよびフ アイバ間げきの区別を省略し，バンドル声径と受光角 のみを考虑して集炎率を計算した結果を図 3 亿示す。 $\langle 2 \cdot 2\rangle$ 節の光子の出射率と比較して，集光率は全般に 低い值となっている。これは前述の光ファイバ受光角 やバンドル直华による制限が付加されたためである。 $25.4 \mathrm{~mm}^{\phi} \times 25.4 \mathrm{~mm} \mathrm{NaI}(\mathrm{TI})$ シンチレータに㮌次直 径の小さいバンドルを組合せた場合，接続するバン ドルの直径が $15 \mathrm{~mm}$, 両者の断面積比にして約 0.4 よ り小さくなると急激に集光率が低下する。これは 〈2・2〉節で示したように，シンチレータから出射する 光子加出射面の中心部に多く分布しているととによ る。従って，大形のシンチレータと断面積比が 0.4 より小さい直径のバンドルを直接接続することは望ま しくない。

一方, シンチレータの長さを $25.4 \mathrm{~mm}$ 一定とし， 直径をバンドルに合せて小さくした場合，両者の断面 皘比は不変であるが，光子の出射率が低下するので測 定系全体では策光率の㻮立った改善は見られない。

また，同じ形状の $\mathrm{NaI}(\mathrm{Tl})$ と BGO シンチレータ を用いる測定系を比較すると，実効的な受光角加ら予 想されたように前者のほうが高い集光率が得られた。

シンチレーション発光点による集光率の変化を図 4 に示す。 $25.4 \mathrm{~mm}^{\text {中 }} \times 25.4 \mathrm{~mm} \mathrm{NaI}(\mathrm{Tl})$ シンチレー夕 に直经の小さいバンドルを組合せた場合で、バンドル 直径が約 $10.0 \mathrm{~mm}$ 以上の湘定䌽，あるいはバンドル と同直径のシンチレータを用いる测定系では接合面か ら遠い点活じ集光率は高い。逆に，バンドル直径が $10.0 \mathrm{~mm}$ 未満の測定系では接合面に近い点ほよ゙高い 集光率を示した。前者の場合は光ファイバの受光角に よる制限が支配的であるのに対し，後者の場合には発
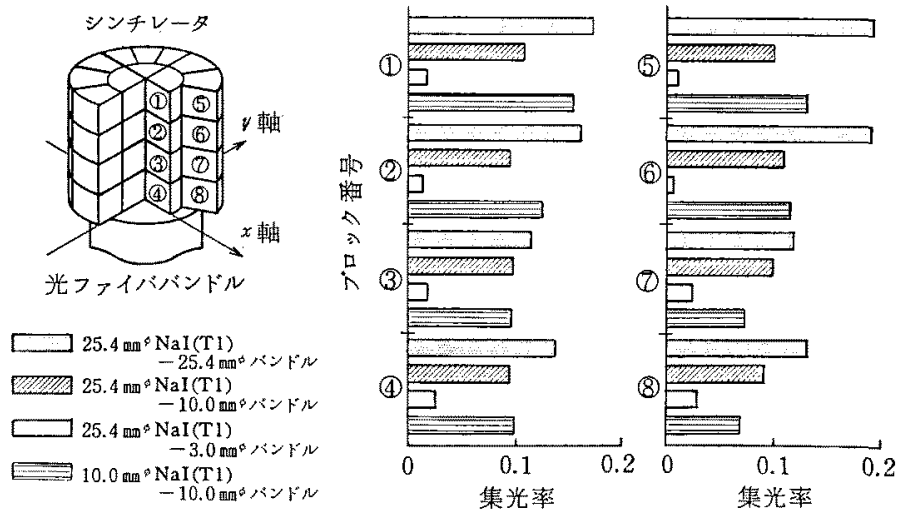

図 4 発光点による光子の集光率の変化

Fig. 4. Scintillation collection efficiency relative to each scintillation point. 
光点から接合面を見た立体角が支配的であることによ るあのと考えられる。

\section{3. 害験}

〈3.1〉実験装置実験に用いた光ファイバ式シ ンチレーション測定系の構成を四 5 亿示す。シンチレ 一タと光電子增倍管の間に光ファイババンドルを捙入 しているほかは，従来の測定系と同じである。実験に 使用したシンチレータ, 光ファイババンドル抢よび光 電子增倍管の仕槏を表 2 亿示した。

光ファイバは，高純度メタアクリル樹脂 (PMMA) のコアとフッ素樹脂のクラッドからなるアクリル系フ アイバで, シンチレータおよび光電子堌倍管とは光学 セメント OKEN 6262 を用いて直接接続しだ。てれ らの光学系全体は黒布によって遮光している。光電子 増倍管加らの信号は比例增幅器で增幅した後, 多重波 高分析器で $\gamma$ 線スペクトルを観測すると共に，シンチ レーションの全計数値を求为た。

〈3.2〉遮光マスクによる実験北ファイバ式測 定系の特性を調べるのに先立ち, シンチレータの出射 面皘の減少が $\gamma$ 線検出特性に与える影響について検討 した。

$25.4 \mathrm{~mm}^{\phi} \times 25.4 \mathrm{~mm} \mathrm{NaI}(\mathrm{Tl})$ シンチレー夕之光電 子增倍管の接合面に厚さ $0.02 \mathrm{~mm}$ の思紙の遮光マス

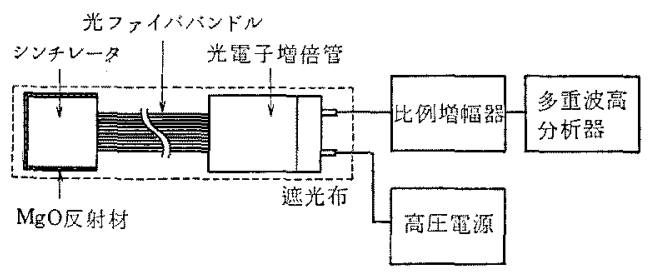

图 5 光ファイバ式シンチレーション測定系

Fig. 5. Schematic diagram of a scintillation counting system incorporated with an optical fiber bundle.

\section{表 2 実験器具 0 仕様}

Table 2. Specification of the experimental apparatus and parts.

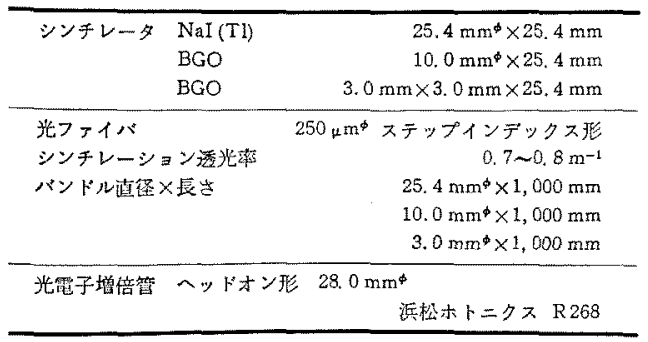

クを摴入し、マスク中央にあけた穴の直径を変化させ て観測した ${ }^{60} \mathrm{Co \gamma}$ 線スペクトルを図6 (a) に示す。光 電子增倍管の電極印加電圧ならびに增幅器の利得は一 定である。ケ線スペクトル分布はマスク穴の直径が さくなるにつれて低チャンネル箕域に移動し, $15 \mathrm{~mm}^{\phi}$

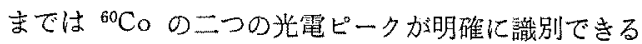
が, $10 \mathrm{~mm}$ 中では識別不可となる。そして $5 \mathrm{~mm}^{\phi}$ では すべての波高値が弁別レベル以下となり，計数は全く 得られない。このようにて線エネルギーに対するチャ ンネル值が变化するため，以後，波高値はチャンネル 番号で表す。

マスク穴の面蝵と総計数值，最大波高值ならびにも ンテカルロ法で求めた集光率を規格化したものを図 6 (b)化示す。最大波高值执よび集光率計算值の変化, ならびに光電ピークが不明りょうになるととから波高 值の減衰は非線形であり，複雑な過程を経ているもの と考え弓れる。マスク穴の面皘の縮小代伴う総計数值

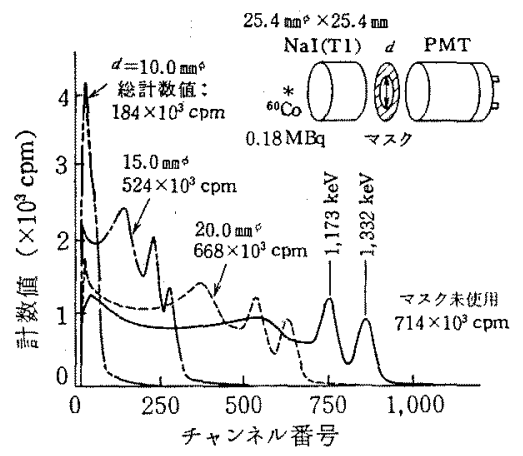

(a) ${ }^{60} \mathrm{Cor}$ 線スベクトN

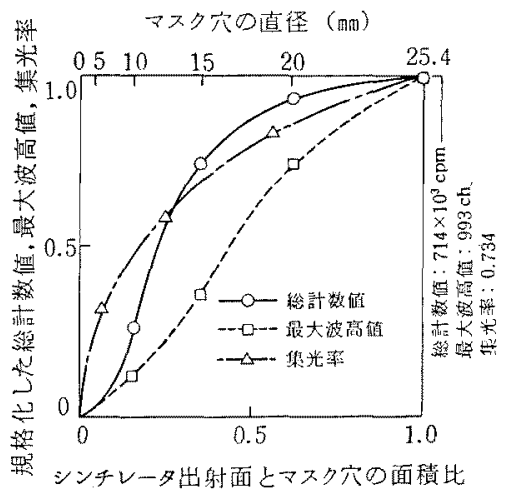

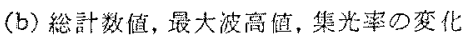

図 6 遮光マスクを搟入したシンチレーション 测定系の特性

Fig. 6. Characterization of a scintillation counting system installed with a holed optical mask. 
の减少は，波高分布の低エホルギー部が升别レベル上 下に減衰するととに起因している。すなわ方，穴の面 積が大きく波高值の減衰が小さい間は散乱線領域が升 別されるので計数値の娍少はわずかであるが，穴の面 皘が小さくなると光電ピーク領域が弁別されるように なり，計数值の減少は著しくなる。檤って，計数値は 增幅器の利得を上げることにより減衰分を回復できる あのと考えられる。

\section{〈3・3〉 バントル直径と測定系の利得の影響}

$25.4 \mathrm{~mm}^{中} \times 25.4 \mathrm{~mm} \mathrm{NaI}(\mathrm{Tl})$ シンチレータを用い, てれに 25.4, 10.0 および $3.0 \mathrm{~mm}^{\phi}$ の光ファイババン ドルを組合せた測定系で測定した ${ }^{137} \mathrm{Cs} \gamma$ 線スペクト ルを図 7 に示す。比较のためにバンドルを使用しない 場合の特性も示し, 増幅器の利得を变化させて観測し た。また，光電子増倍管の印加電王は $-1,300 \mathrm{~V}$ で一
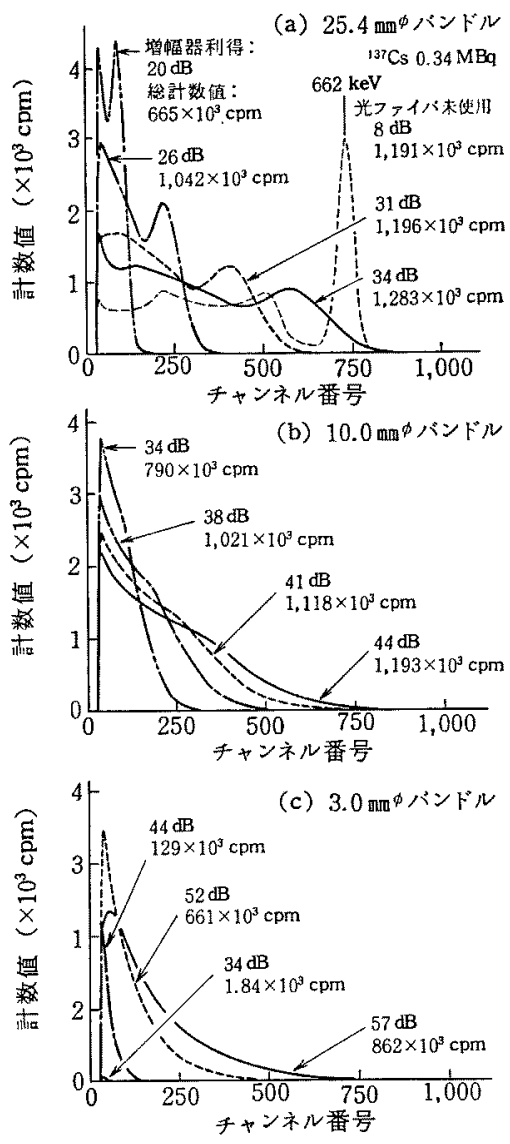

困 7 增幅器利得による ${ }^{137} \mathrm{Cs} \gamma$ 線 スペクトルの变化

Fig. 7. Variation of ${ }^{137} \mathrm{Cs}$ gamma-ray spectrum with linear amplifier gain.
定とした。

光ファイバ式測定系では，遮光マスクを㨉入した場 合亡同様，波高值が娍衰し，波高分布无大きく变化す る。バンドルの長さは $1 \mathrm{~m}$ と短いので, バンドルの有 効受光面樍と光ファイバの受光角が光損失の主因之考 えられる。一方，波高分布の変化はこれらの光損失に 加えて，光ファイバのモード分散 ${ }^{(8)}$ 影響している。

函7のスペクトルにおいて増幅器の利得が $34 \mathrm{~dB}$ で同一の場合，バンドル直径が小さくなるにつれて最 大波高值，計数值上も低下する。（c） $3 \mathrm{~mm}^{\phi}$ のバ ンドルを使用した場合には，(a ） $25.4 \mathrm{~mm}^{\phi}$ のバンド ルを使用した㘯合に比べて波高值は $1 / 20$ ，計数値は 1/700に減少している。これらの低下した波高但执よ び棓数值は，增幅器の利得を高めることによって回復 できる。これは〈3.2〉節で述べたうに，低利得では 弁別レベル以下であった信号が利得の増加に伴って弁 別レベルめ上に回復するととによる。しかし，光ファ イバを使用しない場合のようなスペクトルは, 增幅器

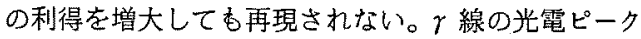
はバンドル直径が小さいほど錍くなり，3 $\mathrm{mm}^{\mathbf{4}}$ バン ドルを用いた測定系では全く認められない。

〈3.4〉 光路直径が同じ測定系の特性 直径 25.4, 10.0 および $3.0 \mathrm{~mm}^{\phi}$ のバンドルに，そ㧈ぞれ直径 の等しいシンチレータを組合せた測定系で測定した ${ }^{60} \mathrm{Co},{ }^{137} \mathrm{Cs},{ }^{241} \mathrm{Am}$ の三種類の $\gamma$ 線スペタトルを図 8 に示す。ことで，比例增幅器の利得は，それぞれの計 数值が光ファイバを使用しない場合とほぼ等しくなる ように調整した。利得の增加は 10〜20倍程度である。 また，エネルギーの高い ${ }^{60} \mathrm{Co} ゃ{ }^{137} \mathrm{Cs} \gamma$ 線の測定で は光電子增倍管の印加電圧を $-1,000 \mathrm{~V}$ とし，エネ ルギーの低い ${ }^{241} \mathrm{Am} \gamma$ 線の测定では $-1,300 \mathrm{~V}$ とし て測定系の利得を前者より約 4.8 倍高めた。

この場合も光ファイバを用いることにより，波高分 布は大きく変化する。図 80 光電ピ一クに注目すると 低于ャンネル睢に移陲し，ての幅が広がって分解能が 低下している。 ${ }^{60} \mathrm{Co} の 2$ 種類の $\gamma$ 線の光電ピークは 光ファイバを用いない場合には尔離，観剆できるが， 光ファイバ式測定系では分離できない。

しかし，10 $\mathrm{mm}^{\phi}$ シンチレータと $10 \mathrm{~mm}$ 中バンドル を組合せた湘定系では，〈3.3〉節で示した $25.4 \mathrm{~mm}^{\phi}$ $\mathrm{NaI}(\mathrm{Tl})$ シンチレータと $10 \mathrm{~mm}$ めバンドルを組合せた 場合と異なり光電ピークか明確で，もとの部数值を得 るために必要な增幅器利得の增加も少なくて上い。 $3 \mathrm{~mm}^{\phi}$ バンドルを用いた测定系では，シンチレータ が小さいので高エホルギー $\gamma$ 線ほど検出効率が低く， 光電ピークが不明りょうとなる。特に ${ }^{60} \mathrm{Co} \gamma$ 線に対 


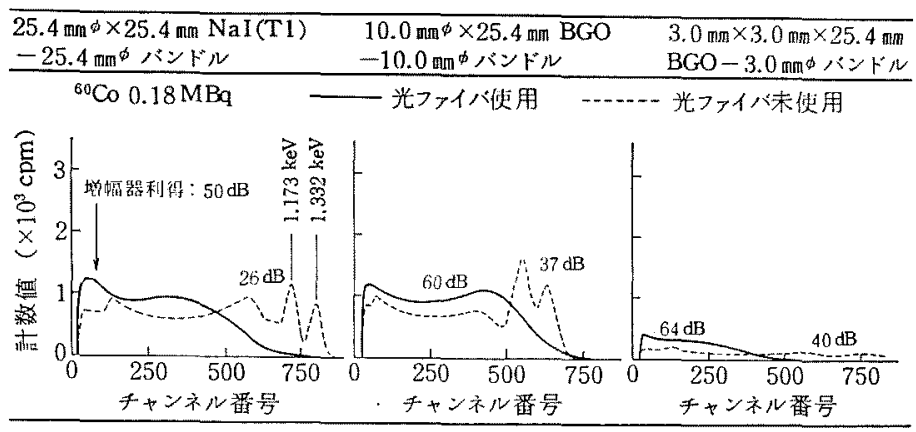

${ }^{1.37} \mathrm{Cs} 0.34 \mathrm{MBq}$
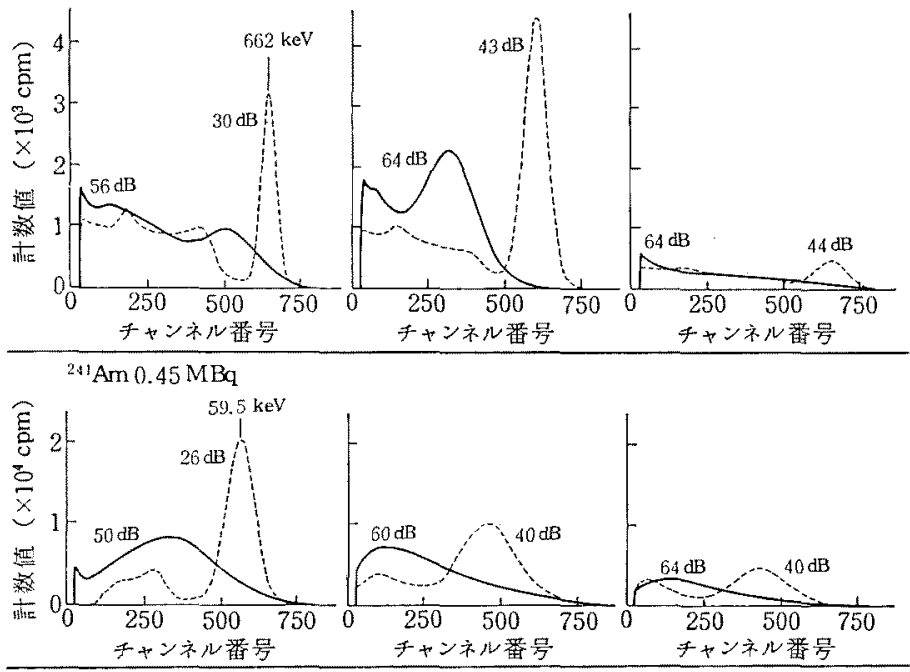

図 8 光ファイバ式シンチレーション測定系で得られた $\gamma$ 線スペクトルの例

Fig. 8. The gamma-ray spectrum obtained with various scintillation counting systems using optical fiber bundle.

しては，光ファイバを使用しない場合であ光電ピーク の識別か涃難である。しかしながら，もとの計数值を 得るために必要な利得の增加は, やはり $25.4 \mathrm{~mm}^{\phi}$ シ ンチレータと組合せた場合よりあ少なくてよい。シミ ニレーションではシンチレータとバンドルの光路直径 が異なる場合上同じ場合で集光率に大差はなかった。 しかし，光ファイバのコア面積で決まる有効受光面皘 は，計算で設定したバンドル断面積より大幅に小さい ため，相対的に光路直径が等しいほうが光損失が少な いあのと考えられる。

以上より，光ファイバ式シンチレーション測定系は $\gamma$ 線強度の検出は容易であるが, $r$ 線エネルギーの検 出は困難である。従って, 連続鋳造朋の電磁汃くはん 炡汇おける 中での線量モニタ ${ }^{(10)}$ なビ、計数のみを取扱う測定に 適用するのがよい。

\section{4. 光損失に関する考察}

〈4・1〉光ファイバの透光率今回の実験では長 さ $1 \mathrm{~m}$ のアクリル系光ファイババンドルを用いたが, 実際には西化延長を必要亡する場合がある。このよう な場合には，ファイバ内における光損失を㧕制するた ぬ，透光率の高い石英系の光ファイバを用いたは主うが よい。

また，多量の放射線照射を受けると光ファイバは 発光や着色儿上り透光率が变化する。高純度メタ了 クリル樹脂の損傷を受けない放射線量は $0.02 \mathrm{MGy}$ (2 Mrad) 程度 $(11)$ なので，放射線レベルが非常に高い 場合には耐放射線性に算れた光ファイバが必要にな $3^{(12)}$ 。

$\langle 4 \cdot 2\rangle$ 有効受光面積と受光角 放射線レベルが 低く，光ファイバの長さが短い場合には，光ファイバ 
バンドルのコア面皘で決まる有効受讯面皘と光ファイ バの開口数で決まる受光角が光損失の主因となる。 〈3.4〉節で述べたように, 直径の小さいバンドルを用 いる場合には，こ机等しい直径のシンチレータを組 合せるほうが光損失が少ない。またシンチレータの届 折率空気よりも高いので，てれに接合する光ファイ バの実効的な受光角縮小させる。この点, $\mathrm{NaI}(\mathrm{Tl})$ と BGOでは届折率の小さい前者のほうが受光角の縮 小が少なく，汅提失が少ない。

一方，透光率や挝放射線の点で有利な石英系の光フ フイバは開口数 0.2 前後の6のが多く(13)，一般に受 光角が㹨い。従って, 石英系の光ファイバ在用いる測 定系ではシンチレーション集光率が变化し，アクリル 系ファイバを用いる测定系しは珙なる $\gamma$ 楾検出特性を 示す向の之考元られる。

〈4.3〉接合状態 シンチレータと光ファイババ ンドル，ならびに光ファイババンドルと光電子堌倍管 の接合状態が悪いと大きな光損失を生じるが，これは 十分な端面処理や接合器具の加工精度を向上すること で軗減できる。

\section{5.あとがき}

光ファイババンドルを使用するシンチレーション测 定系では，バンドルを使用しない测定系に比べて波高 值，計数值ともに減少するが，これらは増幅器の利得 を上げることにより回復するととができる。しかし， 大幅な光䅡失などによってエネルギー分解能が低下 し，光電ピークは崩れてくる。従って，r線強度の检 出は容易であるが $\gamma$ 線エネルギーの检出は困難である ので，計数のみを取扱う計测に適する。

放射線のレベルが低く，光ファイババンドルの長さ が短い場合には，バンドルのコア面積で決まる有効受 光面積と光ファイバの開口数で決まる受光角が検出效 率に影響する光賣失の主因となる。従って，直径の小
さいバンドルを用いる場合には，乙れに等しい直栙の シンチレータを組合せるとよい。また，BGO シンチ レータより届折率の小さい $\mathrm{NaI}(\mathrm{Tl})$ シンチレータを 用いたほうが光ファイバの実効的な受光角が大きく， 光損失の軽減に有利である。

最後に，実験の一部で協力を得た山根康徳氏【現在 横河電機(株)」に謝意を表する。また，本研究の一部 は文部省科学研究費奖励研究 (A)の補助を受けて行っ た。

(昭和 63 年 2 月 25 日受付, 同 63 年 6 月 15 日再受付)

\section{文献}

(1) Y. Higashiyama, T. Konno \& S. Enomoto: "Use of an Optical Fiber Cable in Scintillation Counting System", Radioisotopes, 33, 89 (1984)

（2）小管・飯田・住田・田中・木村：「低提失光ファイバを利用 した垛射線测定系」, 昭 59 日本原子力学会分科会C 2，p，174

（3）松下：「光ファイバ式連鋳レベル培」，第 17 回日本アイソト

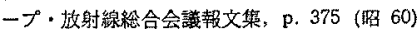

(4) H. Uchida, Y. Yamashita, T. Yamashita \& T. Hayashi "Advantageous Use of New Dual Rectangular Photomultiplier Tube for Positron CT", IEEE Trans. Nuclear Sci., NS-30, 451 (1983)

(5) F. Adams \& R. Dams: Applied Gamma-Ray Spectrometry, 2nd edition and revision of original publication by C.E. Crouthamel, p. 39 (1970) Pergamon Press

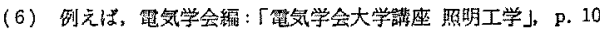
(昭 53)

(7) 同上, p. 169

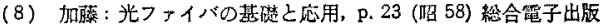

（9）神田・新田・榎本:「花ファイバ式 $\gamma$ 線散乱型密度計」, Radioisotopes, 37, 513 (1988)

(10)蚂田・束山・榎本：「光つナイバ式シンチレーション検出器

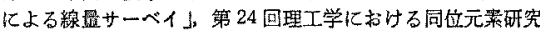
発表会, 30 a-I-3 (昭 62)

(11) G. Földiák (editor): Industrial Application of Radioisotopes, revised and enlarged version of original publication by Müszaki Könyvkiadó, p. 415 (1986) Elsevier Science

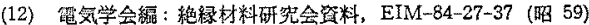

(13) オプトロニクス，1，72 (昭 57) 